\title{
Organizational Change in Public Service
}

\author{
Dian Ekowati \\ Department of Management, Faculty of Economics and Business Airlangga University, Indonesia \\ Jl. Airlangga 4-6, Kec. Gubeng, Kota SBY, Jawa Timur 60286
}

\begin{tabular}{|c|c|}
\hline ARTICLE INFO & A B S T R A C T \\
\hline $\begin{array}{l}\text { Keywords: } \\
\text { Organizational Change, } \\
\text { public service, } \\
\text { innovation, } \\
\text { Indonesia, } \\
\text { institutional logics }\end{array}$ & $\begin{array}{l}\text { This study aims to investigate institutional logic underlying the initiation } \\
\text { of the change management process in public sector organizations. } \\
\text { Organizational Institutionalism is used to frame the analysis. The study } \\
\text { itself took place in three different public organizations in the Province } \\
\text { of East Java, including a one-stop service for licensing as well as that of } \\
\text { vehicle registration, taxing, and insurance and also from the local health } \\
\text { authority. The qualitative method was employed to analyze information } \\
\text { gathered through semi-structured interviews with } 35 \text { respondents. Data } \\
\text { were analyzed by using an approach informed by grounded theory. } \\
\text { The study unveiled various institutional logics underlying the adoption } \\
\text { of changes and innovation in organizations. It ranged from the most } \\
\text { common reason for improving performance gaps up to the need to clean } \\
\text { the organization's name and build a better image. The study contributes to } \\
\text { the idea that an organization's previous experiences, as well as perceived } \\
\text { institutional character, affect the need to conduct changes. }\end{array}$ \\
\hline
\end{tabular}

\section{SARI PATI}

Studi ini bertujuan untuk menyelidiki logika kelembagaan yang mendasari inisiasi proses manajemen perubahan di organisasi sektor publik. Kelembagaan digunakan untuk membingkai analisis. Kajian itu sendiri dilakukan di tiga organisasi publik yang berbeda di Provinsi Jawa Timur, termasuk pelayanan satu pintu untuk perizinan, STNK, perpajakan dan asuransi serta dari dinas kesehatan setempat. Metode kualitatif digunakan untuk menganalisis informasi yang dikumpulkan melalui wawancara semi terstruktur dengan 35 responden. Data dianalisis dengan menggunakan pendekatan yang diinformasikan oleh grounded theory. Studi ini mengungkap berbagai logika kelembagaan yang mendasari adopsi perubahan dan inovasi dalam organisasi. Mulai dari alasan paling umum untuk meningkatkan kesenjangan kinerja hingga kebutuhan untuk membersihkan nama organisasi dan membangun citra yang lebih baik. Studi ini berkontribusi pada gagasan bahwa pengalaman organisasi sebelumnya serta karakter institusional yang dirasakan mempengaruhi kebutuhan untuk melakukan perubahan. 


\section{INTRODUCTION}

The reform movement that has been started in the 1980s in many Western countries, including the United Kingdom (UK), the United States of America (USA), and also New Zealand (NZ) offers a new way of managing public service, in a way that public sector organizations (PSOs) need to manage the public as their customers (Bouckaert, 2008). Since then, topics related to public service change become major themes for studies in public sector organizations.

Based on accessible literature from 2000-2014, there are several topics commonly emphasized by the existing studies, namely how change and innovation are related to reform movement (i.e. Kraemer and King, 2006 about information technology and administrative reform; Nieto Morales, Wittek, and Heyse, 2013 about changes after reform in the Netherland), factors triggering change and innovation (i.e Beerepoot and Beerepoot, 2007 about the roles of government regulation in driving innovation and change), as well as the factors contributing to the successfulness or even failure of change implementation (i.e Bartlett and Dibben, 2002 about innovation in local government and entrepreneurship) and the impact of change and innovation to public sector organisations (see for example, Worrall, Cooper, and Campbell- Jamison, 2000 on the impact of change on public sector managers). Small numbers, yet, challenging works on organisational change and corruption are also worthy to note. An example is the work of Martin, Johnson, and Cullen (2009) that focuses on exploring deinstutionalisation of normative control in organisations that leads to the occurrence of corruptions. These works are mostly written on the Anglo-American (European, American or Western) context (Batley, 1999b) and small, yet growing numbers are conducted in Eastern and/or Asian context along with emerging reform movement in Asia (Beeson, 2001). It is worthy to note that whilst reform movement is universal, its impact on organisational reform is argued to be influenced by locality issues, including local interests and circumstances (Batley, 1999a).
In 1998, as a nation, Indonesia had gone through a significant event, a regime change, which contributed to the changes in various aspects of governance and government in both national and local levels (Masduki, 2007). Reformation process ended the 32-year-long Soeharto's regime, which was considered responsible for social and political crisis for issues of 'Korupsi (corruption), Kolusi (collusion) dan Nepotisme (nepotism)', or in Indonesian acronym, KKN, which was believed to become major source of poor performance of public service organisations as well as for economic problems (that is, high dependency on foreign debt) (LintasTerkiniNews, 2013).

Shortly after the regime change, the new administration introduced an initiative to decentralise significantly many of its functions and responsibilities to local government, including provincial and town/regency government levels. Through the Laws numbers 22 and 25/1999, the Central Government devolved its powers and transferred considerable amount of its authority to local governments, thus giving considerable autonomy for local governments to manage their regions (Brodjonegoro and Asanuma, 2000; Hofman and Kaiser, 2002). Decentralisation provides liberty for local government to choose what "path to development' they consider as best for their regions (TheAsiaFoundation, 2004, p. 16). Consequently, local governments needed to find ways to increase their revenues and increase financial resources to develop their regions (TheAsiaFoundation, 2002; Usman, 2002). Decentralisation initiative is intended to bring decision making process closer to public and thus, make public service delivery better and raise the accountability of government (Brodjonegoro and Asanuma, 2000; Hofman and Kaiser, 2002). This initiative is known as 'Decentralization Big-Bang' due to its large scale, involving political, administration and fiscal aspects, and also its speedy target implementation (Alm, Aten, and Bahl, 2001). This initiative was expected to help enhance accountability of public service organisations, improve organisational 
practice transparencies, promote competitions to ensure efficient operations, improve human resource management practices, increase initiatives development to vulnerable groups and community empowerment, as well as encourage more awareness to reorganise structures and improve efficiency and effectiveness of services (Mera, 2004; Subagio, 2005).

Various changes have been proliferated since that time. Many studies on government changes and innovation initiatives have been conducted. Altogether, as network governance and collaboration became an interesting way to manage public organisation (Agranoff, 2007), it is then intriguing to explore how the reform brought changes to that type of organisations, from an organisational perspective. It is also important to explore how interorganisational collaboration, especially those having longer collaboration time frame, experience changes, considering that there are multi organisations with different lines of commands.

This study is interested to capture this dynamic through the perspective of institutional logics. Institutional logics was first identified by Friedland and Alford (1991). This logic does not only represent different belief, but it can also reflect on differences -or even contradictory-- in organisational practices amongst institutions (Thornton, 2004, p. 83). In other words, different logics may lead to different ways of understanding a problem as well as defining solution to a particular problem.

In light of this matter, this study aims to investigate how institutional logics may shift overtime, which as consequences may potentially affect how organisations deal with different kinds of changes. This study intends to contribute in enriching literature of neo-institutional theory, more specifically, in closing the gap in understanding how such logics are co-existent as well as competing in the setting of multi-organisations in conducting changes.
The rest of the paper delineates both review of relevant literature in the area of the management of changes and innovation in public sector organisations as well as institutional logics.

\section{Literature Review}

This section discusses relevant literature related to public service changes, interorganisational collaboration and also territoriality. While management of change literature helps in understanding the major reasons why changes and also innovation take place in organisations, both interorganisational collaboration and territoriality literature are expected to assist in framing the phenomena occuring in organisations.

\section{Changes and Innovation in Public Services}

There is a notably increase in public expectation (and also decrease in public satisfaction) toward the performance of public organisations in delivering services (Borins, 2001; Flynn, 2007; Pollitt, 2003). This implies that public get more awareness toward the quality of services that they receive from public organisations, and compare them to services they enjoy from private organisations. Consequently, this raises the pressure for public service organisations to improve their performance as well as open the opportunities for private sector provision of public services (Albury, 2005; Box, 1999; Dunleavy and Margetts, 2000; Hartley, 2006). This leads to the advocacy of competition and also market-type mechanism (MTM) (Ferlie, Pettigrew, Ashburner, and Fitzgerald, 1996; Flynn, 2002, 2007; Larbi, 1999; Pollitt, 2003).

As an impact of rising public expectation, some authors agree that there is urgency for the advancement of information technology in public organisations' practices (Dunleavy and Margetts, 2000; Greer, 1994; Pollitt, 2003). Indeed, as stated by Pollitt, that public services can be provided in faster and cheaper ways -that leads to cost efficient ways of doing things-by employing relevant information technology tools (Dunleavy and Margetts, 2000; Pollitt, 2003). 
In the literature of public service changes, the notion of change and innovation, somehow, are considered as an overlapping phenomena. Innovation can also be understood as change process and to do so, a learning process should take place (Bekkers, Edelenbos, and Steijn, 2011; Drucker, 1985). Yet; there are differences between these two phenomena (Osborne and Brown, 2005). For the authors, change can be understood as a phenomenon involving development or evolvement of public service elements, such as service design, organisational structure as well as the improvement of skills required to deliver related services. While for innovation, it is actually a part of change that has a discontinuity nature, or following Osborne and Brown (2005, p. 5), 'innovation is discontinuous change'. This aligns with Schumpeter (1942), who understands that innovation as a creative destruction process based on existing resources and transform economy to a different level. More specifically, he emphasises it as 'new combinations of existing resources'. On Schumpeter's term, innovation may present in the forms of new product, method of production, new supply sources, line and distributions of products, as well as new ways of managing business (Schumpeter, 1934, 1942). In general, the main dimension of innovation through Schumpeter's perspective relates to 'newness', which mostly associated to the manufacturing of goods or productions. Most attempts to define innovation mostly refer to Schumpeter's ideas (Porter, 1998; Walker, 2006).

Bringing it into the context of public services, most of public sector organizations understand that only by conducting changes and innovation, they will strive to grow and develop (Thompson and Riccucci, 1998; Thompson and Ingraham, 1996; VigodaGadot, Shoham, Schwabsky, and Ruvio, 2005). This leads to the need for public sector organisations to have flexibility, routinisation and adaptation to change, innovation and entrepreneurial activity (Frederickson, 1996; Hartley, 2006; Walker, Jeanes, and Rowlands, 2002). Meanwhile, some studies assert that innovation in public service is very much laden with administrative/political belief at particular time (Kling and Iacono, 1989; Kraemer and Dedrick, 1997; Kraemer and King, 1986, 2006; Kraemer and Perry, 1989; Niehaves, 2007). Peled (2001, p. 200) argues that 'innovation in the public sector is a highly politicized process'. His study provides insight for the critical roles of issue network, coalition around innovation and also institutionalisation. This aspect contributes to establish a difference between private and public sector innovation as well as the question of why some public organisations innovate better than others within similar institutional context.

\section{Institutional Logics}

Institutional logics is one aspect of institutional theory, especially neo-institutional theory in organisational studies (Friedland and Alford, 1991). The institutional theory itself is actually multifaceted as it has aspects rooted in politics, economics as well as sociological science (Scott, 2008). Institutional logics was first identified by Friedland and Alford (1991) by emphasising on various key institutions, which are Christianity, Capitalist, Bureaucratic, Nuclear family and also Democracy. As for Thornton (2004), she offers a rather different sort of institutions, which are the market, the state, the corporation, religion, profession and also the family. In 2012, (Thornton, Ocasio, and Lounsbury, 2012) add one more key institution on the list, which is community. Whilst offering different key institutions, these scholars emphasise that each of these institutions is grounded on different and distinctive institutional logics. More specifically, Thornton (2004, p. 70) states that institutional logics provide "assumptions and values, usually implicit, about how to interpret organizational reality, what constitutes appropriate behavior, and how to succeed".

This logic does not only represent different belief, but it can also reflect on differences -or even contradictory-- in organisational practices amongst institutions, for example on leadership and power practices (Thornton, 2004, p. 83). According to 
Ocasio (1997), decision makers might come out on different solutions on similar problems when they are influenced by different dominant logic. On this ground, citing Thornton and Ocasio (1999), institutional logic can be defined as "the socially constructed, historical patterns of material practices, assumptions, values, beliefs, and rules by which individuals produce and reproduce their material subsistence, organize time and space, and provide meaning to their social reality".

With regards to the level of analysis, previous works show that logic can work in understanding institutions or inter-institutions level or at the level of individual or society level (Friedland and Alford, 1991). In this sense, institutional logics can be conflicting or competing (Hayes and Rajão, 2011; Thornton and Ocasio, 2008). It may not be ever resolve, yet, emerge as a blended logic within an institution (Thornton, Jones, and Kury, 2005). This reflects the dynamics in both within institutions and inter-institutions (Thornton and Ocasio, 2008). Consequently, this does not mean that such situation is trouble-free. An example given by Tilcsik (2010) in his study on a post-communist government agency in which there is a conflict between old regime and new regime institutional actors. Related to change process, different institutional logics may bring different consequences on how changes take place as well as may lead to the occurrence of change (Thornton and Ocasio, 1999). Referring back to Tilcsic's study, this show that institutional logics indeed could be used to frame an analysis on organisational practices, success and even fail stories as well as change processes.

\section{METHODS}

In exploring how an inter-organizational agency implemented organizational change, this study purposively approached an organization, which represented the context of inter-organizational collaboration. This choice of determining the research setting aligns with the idea that the objective of this study is not to seek generalization or 'universal rules' (Aaltio and Heilman, 2010, p. 68).
Instead, the objective is to explore the organizational phenomena, which is important to comprehend the case and its specific environmental characteristics. Furthermore, as argued by Bleijenbergh (2010, p. 61 ), 'case selection is the rational selection of one or more instances of a phenomenon as the particular subject of research. Therefore in employing this rational selection, some aspects of the organization were considered, including first, its characteristics of being a public institution; second, the organization comprised three collaborating organizations and third, the organization was understood to engage with several changes and innovation programs over the last thirty years. On this consideration, a longterm mandated inter-organizational collaboration, comprising three different organizations, was chosen as it was able to provide the most relevant setting for understanding the dynamics of changes in an inter-organizational context. However, for ethical reasons, this study committed to maintaining the anonymity of both individuals and organizations involved in this research. Hence, the two multiorganizational contexts were identified only as ILGa (for the public institution responsible for vehicle registration, vehicle taxing, and accident insurance) and ILGb, which represents a collaboration between the international aid body and local health authority.

To help with the investigation, this study employed a qualitative method, by using an approach informed by grounded theory. A qualitative method was chosen as the most suitable method to approach the phenomena as it helps to explore contextual explanation as well as the situated meaning and reveal prominent issues (Tracy, 2013). By employing a qualitative method, a more holistic view is expected to be gained as well as a comprehensive understanding of the situation (Huberman and Miles, 1994). In breaking down collected information and mapping the results, the method informed by the grounded theory approach helped to ask questions on who, what actions, what context, what aims, how they did it, and also how the conduct was. Data was collected through the use of semi-structured interviews with 16 informants, who were contacted through 
a snowballing mechanism. These informants included heads and staff from three collaborating organizations, who were involved in change programs initiated by organizations. Supporting documents were also collected from the organizations involved, as well as publicly available documents, to help with the analysis.

\section{FINDINGS AND DISCUSSIONS}

In general, this study was able to find that there are some logics underlying changes in public sector organizations. Such logics were found not only lead to change but also to some extent, was perceived by respondents to hinder changes. It is also important to note that the study found the existence of competing logics within

organizations. These logics are also evolved over time along with the development in external environments of those organizations under study.

\section{Initial Development - Closing Internal Performance Gap}

It was found that the reasoning process of the need for changes in was related to how people experienced and perceived gaps in their organizations' performance. For the case of ILGA, for example, whilst the process of assessment itself was informal, in a way that it was based on how its collaborating organizations looked at their shared difficulties in dealing with ILGA's operation, people came out with what they perceived as the gaps that needed to be dealt with.

In its early development, ILGA handled and recorded all transactions manually. The hard copies of all transaction forms and vehicle records were kept in ILGA's archival room, which was not adequate to hold large numbers of documents. This situation was further worsened by the fact that internal staff lacked the ability to maintain records. As stated;

'Public service officers working in public organizations did not have the habit to do documentation to keep records. They were not used to document anything.' (ILGA-

Former EDP Senior Staff)،

Notably, the habit of not maintaining documents properly is a common problem in public organizations in Indonesia. Several publications (e.g. Badudu, 2012; Indopos, 2011; RadarBangka, 2012) report of what it seems to be an institutional problem at large, which is about the poor archival database or documentation systems of public sector organizations from central government levels such as ministries, down to the local units. The Republic of Indonesia's National Archival Agency (ANRI, Arsip Nasional Republik Indonesia) also points out that the poor archival management in local levels is due to the low quality and quantity of personnel and limited budget allocated for archival management. The limited use of information technology in archival and database management also contributes to the problem (ANRI, 2010).

\section{Post-Reform Period - Mandated Changes and Fulfilling Public Expectation on Improving Performance}

This study found that there were shifts in public organizations' institutional logics in conducting changes. These were evidenced in both organizations under study, especially after reform period, which was started in 1998. For both organizations, they reported that the needs for conducting changes were actually not only mandated by national government but also involving the needs to fulfil public expectation, which -- it is of note-increased after reform period.

As reported by ILGB, the pressure for changes was because they were mandated by its upper organization. In doing so, ILGB was also considered as one of players in public sector innovation projects initiated by an international aid body in light of assisting Indonesian government in improving the quality of public service delivery.

'Yes, we got this mandated and for that we were offered by one of international aid 
body under its collaborating project with some institutions. We were selected to be one of its players as a way to help the local government in conducting changes and improving its performance. We were then introduced to adopt IS change from a neighbourhood municipal.' (ILGB-Secretary of local health authority)‘

At this point, the institutional logics seem to be externally driven, mostly by upper level organizational body. The emphasis was on implementing the regulation initiated by the national government as well as one of major interest holders, which was international aid body.

From institutional perspective, this may relate to the notion of isomorphism (DiMaggio and Powell, 1994), representing the adoption of innovation due to the fact that they become a trend or fashionable in markets (Rogers, 2003). Institutional isomorphism basically can be by coercive (pressure from more powerful institution), normative (learning between institutions), or mimetic (as innovation becomes embedded) (DiMaggio and Powell, 1983). The case of ILGB can also be a good example that the urgency of conducting innovation can be political-based such as pressure from government, international organizations, or even from public at large through pressure groups (Becheikh et al., 2007; Peled, 2001).

It is also crucial to note that public organization could no longer deprive the public's opinion. Prior reform era, Soeharto's regime imposed strict regulations on how people could express their opinion, which resulted in the lack of freedom of speech and information (Bhakti, 2004; McCargo, 2003). Evidence for this strict regulation is also shown through the banning of three publications in 1994 (Bhakti, 2004). One of the important findings related to this was the impossibilities of turning back from the road of changes. Both ILGA and ILGB admitted that it was impossible for them to return back to the condition or state before changes took place. The main reason for this was because the public had experienced such improvement on the service delivery, and consequently, none of them would like to let go the convenience as well as the easeness of getting services from relevant public sector organizations.

'It was not possible to stop the change or even just to turn back to previous practices. The public has been enjoying an improvement and there will be such impossibility to taken that convenience from them (ILGA-Head of EDP/IS Division)‘

This to some extent, also shows a slight shift of institutional logics in a way that both organizations could not get away of what they had started, and there was no choice except continuing the changes or sustaining the practices. Unfortunately, this shift of logic did not seem to match with previous logic in which organizations were mandated. ILGB for example, reported difficulties as they did not have more support from external body with regard of sustaining innovation.

'it does not seem good for us. At one point, we know we cannot withdraw the change as the public has experienced good things about it. Yet, it is also not possible to sustain the change considering that there was no more financial or technical support from the upper bodies (ILGB-Head of community health centre A)

This situation reflects a political process involving power relationships amongst organizations and institutions, and interactions of values and interests held by each member organization (Benson, 1975; Hardy and Phillips, 1998). For some collaboration, political reason is more prominent as organizations need to maintain reputation, prestige and even legitimacy (Rodríguez, Langley, Béland, and Denis, 2007). This also reflects that organizational decision may not only depend on leaders. In literature of innovation and change, the roles of leaders in supporting innovation is by ensuring that the aim 
of innovation is clear and understood as well as that there is a sustainability of access to resources and assurance that such innovative practice is sustained regardless regime change (GouldWilliams, 2004; Walker, 2006). Yet, this case did not seem to conform to this idea. From institutional point of view, organizations and individual actors within their boundaries are ambiguous and may have unpredictable - changeable interest and preferences (March and Olsen, 1996).

\section{Curbing Corruption and Saving Organizational Image}

As found in ILGA, one of the major problem leading to change initiatives were common practice of covert corruption that was also became a major issue during reform period. With no clear guidance in tax assessment process, ILGA staff was able to play around with the system, as the public did not have any idea as to what happened in the system and how they could deal with it. This created a hapless situation in which irresponsible staff forced the public to part with larger sums than required for the service. The large number of staff and no control mechanism worsened this situation.

It was found that potential for bribery practice took place especially when the system was crowded. Lengthy processing times resulted in bottleneck situations where the public queued to enter the process. Overall, this worsened the already negative behaviour. An interviewee stated;

The processes were much longer and took long time to finish, and I guess that was why they kept using middlemen service expecting to speed up the process (ILGA Head of Vehicle Validation Unit)

Such practices disadvantaged the public. Why? In addition to lengthy processing time, they were also required to pay more than what they were supposed to pay if following formal procedures. This created what is called as 'pung-li' or 'pungutan liar', an illegal fee needed to pay to smoothen the process.
In public organizations, cases of corruption have been highlighted to be damaging to the integrity of organizations.

'The public pictured the police as being corrupt and the attention increased after reform (ILGA-Head of Vehicle Validation Unit).

Corruption, collusion and bribery created a difficult situation for everyone, as it could not be differentiated between those organizations involved in the practices and those that were not. It was even more difficult to point to those individuals who were involved, despite every respondent agreeing that such practices were rampant in the office. At this point, the institutional logic underlying change was to fulfil the need to detach organizational image related to corruption. Organizations are subjected to external pressure, which this time, comes from the public with the notion of transparency as well as accountability.

In general, these different logics show that there are various dominant logics that influence the way organizations conduct changes. Such logics also affect how leaders or the organizations react to particular organizational problems. As put forwarded by Dacin, Goodstein, and Scott (2002), organizational players or in the context of institutional theory, is also understood as institutional actors may have different opinion and understanding on how they give meanings to dominant logics as they perceive.

\section{CONCLUSION}

This study discussed different logics underlying changes in public organizations, especially those involving multi-organizational context. The study revealed that organizations facing different logics over time, and some of those logics were in fact competing with each other. This has caused organizations -at some point- did not know what to do. It is interesting that when performance gaps were considered to be no more a problem, the 
dominant logic was to improve organizational image, especially related to the image of being 'free from corruption' organizations. In this sense, transparency and accountability of actions to the public were considered to be the most important things for organizations.

One of the limitations of this current study was related to the need to elaborate the process of institutionalisation. This study was only focused on investigating logics underlying change movement. It did not, however, elaborating on the aspects of actors as well as the idea of institutional isomorphism that might as well contribute to the process of institutionalising changes in public sector organizations. Another limitation related to the snapshot nature of the research. Hence, this study suggests further studies in the area to elaborate longitudinal research method in investigating similar phenomena.

Aaltio, I., \& Heilman, P. (2010). Case Study as a Methodological Approach. In A. J. Mills, G. Durepos, \& E. Wiebe (Eds.), Encyclopedia of Case Study Research (Vol. 1, pp. 66 - 76). London, United Kingdom: SAGE Publications, Inc.

Agranoff, R. (2007). Managing within networks: Adding value to publicorganizations. Washington, D.C.: Georgetown University Press.

Albury, D. (2005). Fostering innovation in public services. Public Money \&Management, 25(1), 51-56.

Alm, J., Aten, R. H., \& Bahl, R. (2001). Can Indonesia Decentralize Successfully?Plans, Problems, and Prospects: United States Agency for InternationalDevelopment (USAID).

Bartlett, D., \& Dibben, P. (2002). Public sector innovation and entrepreneurship: Case studies from local government. Local Government Studies, 28(4), 107-121.

Batley, R. (1999a). The new public management in developing countries: implications for policy and organizational reform. Journal of InternationalDevelopment, 11(5), 761-765.

Batley, R. (1999b). The new public management in developing countries: Introduction. Journal of International Development, 11(5), 755-760.

Becheikh, N., Halilem, N., Jbilou, J., Mosconi, E., Hammami, H., \& Landry, R. (2007). Conceptualization and Determinants of Innovation in the Public Sector: ASystematic Revue. Paper presented at the XVII International RESER Conference, 13-15 September 2007, Tampere, Finland. http://www.reser.net/file/27690/

Beerepoot, M., \& Beerepoot, N. (2007). Government regulation as an impetus forinnovation: Evidence from energy performance regulation in the Dutch residential building sector. Energy Policy, 35(10), 4812-4825. doi: 10.1016/j.enpol.2007.04.015

Beeson, M. (2001). Globalization, Governance, and the Political-Economy ofPublic Policy Reform in East Asia. Governance, 14(4), 481-502.

Bekkers, V., Edelenbos, J., \& Steijn, B. (2011). Linking Innovation to the Public Sector: Contexts, Concepts and Challenges. In V. Bekkers, J. Edelenbos, \&

B. Steijn (Eds.), Innovation in the Public Sector: Linking Capacity andLeadership. Basingstoke, Hampshire: Palgrave MacMillan.

Benson, J. K. (1975). The Interorganizational Network as a Political Economy. Administrative Science Quarterly, 20(2), 229-249. doi: $10.2307 / 2391696$

Bhakti, I. N. (2004). The Transition to Democracy in Indonesia: Some Outstanding Problems. In J. Rolfe (Ed.), The Asia-Pacific: A Region in Transition (pp. 195-207). Honolulu, HI: The Asia-Pacific for SecurityStudies. 
Bleijenbergh, I. (2010). Case Selection. In A. J. Mills, G. Durepos, \& E. Wiebe (Eds.), Encyclopedia of Case Study Research (Vol. 1, pp. 61-63). London, United Kingdom: SAGE Publications, Inc.

Borins, S. (2001). Public Management Innovation in Economically Advanced andDeveloping Countries. International Review of Administrative Sciences, 67(4), 715-731.

Bouckaert, G. (2008). Changing Strategies in Public Sector Reform: New Zealand in an international context. Institution of Public Administration Australia Retrieved from http://www.ipaa.org.au/_dbase_upl/Geert Bouckaert.pdf.

Box, R. C. (1999). Running government like a business: implications for public administration theory and research. The American Review of Public Administration, 29(1), 19-43.

Brodjonegoro, B., \& Asanuma, S. (2000). Regional Autonomy and Fiscal Decentralization in Democratic Indonesia. Hitotsubashi Journal ofEconomics, 41, 111-122.

Dacin, M. T., Goodstein, J., \& Scott, W. R. (2002). Institutional Theory and Institutional Change: Introduction to the Special Research Forum. Theacademy of management journal, 45(1), 43-56.

DiMaggio, P. J., \& Powell, W. W. (1983). The iron cage revisited: Institutional isomorphism and collective rationality in organizational fields. Americansociological review, 147-160.

DiMaggio, P. J., \& Powell, W. W. (1994). The new institutionalism in organizationalanalysis. Chicago: University of Chicago Press.

Drucker, P. F. (1985). Innovation and Entrepreneurship. London: WilliamHeinemann Ltd.

Dunleavy, P., \& Margetts, H. (2000). The Advent of Digital Government: Public Bureaucracies and the State in the Internet Age. Paper presented at the Annual Conference of the American Political Science Association, Washington, D.C., 4 September 2000. http://www.governmentontheweb.org/downloads/papers/APSA_2000.pdf

Ferlie, E. B., Pettigrew, A., Ashburner, L., \& Fitzgerald, L. (1996). The New Public Management in Action. Oxford: Oxford University Press.

Flynn, N. (2002). Explaining the New Public Management. New PublicManagement: Current trends and future prospects, 57.

Flynn, N. (2007). Public Sector Management (5th ed.). London: SAGE PublicationsLtd.

Frederickson, H. G. (1996). Comparing the reinventing government movement with the new public administration. Public administration review, 56(3),263-270.

Friedland, R., \& Alford, R. (1991). Bringing Society Back in: Symbols, Practices and Institutional Contradictions. In P. J. DiMaggio \& W. W. Powell (Eds.), The New Institutionalism in Organization Analysis (pp. 232-266). CHicago:University of Chicago Press.

Gould-Williams, J. (2004). The Effects of 'High Commitment' HRM Practices onEmployee Attitudes: The Views of Public Sector Workers. Public Administration, 82(1), 63-81.

Greer, P. (1994). Transforming Central Government: The Next Steps Initiative. Buckingham, England: Open University Press.

Hardy, C., \& Phillips, N. (1998). Strategies of Engagement: Lessons from theCritical Examination of Collaboration and Conflict in an Interorganizational Domain. Organization Science, 9(2), 217-230.

Hartley, J. (2006). Innovation and its Contribution to Improvement: A Review for Policymakers, Policy Advisers, Managers and Researchers. London: Department for Communities and Local Government Retrieved from http://tna.europarchive. org/20061101222554/http://www.communitie s.gov.uk/pub/177/InnovationanditsContributiontoImprovementAReview FullReport_id1500177.pdf.

Hayes, N., \& Rajão, R. (2011). Competing institutional logics and sustainable development: the case of geographic information systems in Brazil's Amazon region. Information Technology for Development, 17(1), 4-23.

Hofman, B., \& Kaiser, K. (2002). The Making of the Big Bang and its Aftermath: A Political Economy Perspective. Paper presented at the Conference on 'CanDecentralization Help Rebuild Indonesia?, Atlanta, Georgia, May 1-3, 2002, Jakarta, Indonesia. http://siteresources.worldbank.org/INTINDONESIA/Resources/Decentralization/hofmankaiserAtlanta_3.pdf

Huberman, A. M., \& Miles, M. B. (1994). Data Management and Analysis Methods. In N. K. Denzin \& Y. S. Lincoln (Eds.), Handbook of Qualitative Research (pp. 428-444). Thousand Oaks, CA, USA: Sage Publications, Inc.

Kling, R., \& Iacono, S. (1989). The institutional character of computerized information systems. Information Technology \& People, 5(1), 7-28.

Kraemer, K. L., \& Dedrick, J. (1997). Computing and public organizations. Journal of Public Administration Research and Theory, 7(1), 89.

Kraemer, K. L., \& King, J. L. (1986). Computing and public organizations. PublicAdministration Review, $488-496$.

Kraemer, K. L., \& King, J. L. (2006). Information technology and administrative reform: will e-government be different? International Journal of ElectronicGovernment Research, 2(1), 1-20.

Kraemer, K. L., \& Perry, J. L. (1989). Innovation and computing in the public sector: A review of research. Knowledge, Technology \& Policy, 2(1), 72-87. 
Larbi, G. A. (1999). The new public management approach and crisis states: UNRISD - United Nations Research Institute for Social Development.

LintasTerkiniNews. (2013, April 9). Komnas Waspan: Masih Ada SAMSAT di Daerah Lakukan Pungli. LintasTerkiniNews.Com. Retrieved from http://intasterkininews.com/komnas-waspan-masih-ada-samsat-di-daerah-lakukan-pungli.php

March, J. G., \& Olsen, J. P. (1996). Institutional perspectives on politicalinstitutions. Governance, 9(3), 247-264.

Martin, K. D., Johnson, J. L., \& Cullen, J. B. (2009). Organizational Change, Normative Control Deinstitutionalization, and Corruption. Business Ethics Quarterly, 19(1), 105-130.

Masduki, M. (2007). Regulasi Penyiaran: Dari Otoriter ke Liberal (A. Rahim Ed.). Yogyakarta, Indonesia: LKiS.

McCargo, D. (2003). Media and Politics in Pacific Asia. London: Routledge Curzon.Mera, K. (2004). The Big Bang Decentralization in Indonesia and the Lessons Learned. Paper presented at the The International Workshop on Urban Governance in Glocal Perspective, University of Southern California,California, September 17-18, 2004.

Niehaves, B. (2007). Innovation Processes in the Public Sector-New Vistas for anInterdisciplinary Perspective on E-Government Research? In M. A. Wimmer, H. J. Scholl, \& A. Gronlund (Eds.), Electronic Government (pp. 23-34). Berlin: Springer Lecture Notes in Computer Science (LNCS) 4656 Extended Version.

Nieto Morales, F., Wittek, R., \& Heyse, L. (2013). After the Reform: Change in Dutch Public and Private Organizations. Journal of Public AdministrationResearch \& Theory, 23(3), 735-754. doi: 10.1093/jopart/mus006

Ocasio, W. (1997). Towards an Attention-based view of the firm. Psychology, 1,403-404.

Osborne, S. P., \& Brown, K. (2005). Managing Change and Innovation in PublicOrganizations. Oxon, UK: Routledge.

Peled, A. (2001). Network, coalition and institution-The politics of technologicalinnovation in the public sector. Information Technology \& People, 14(2), 184-205.

Pollitt, C. (2003). The essential public manager. Maidenhead: Open University.

Porter, M. E. (1998). The competitive advantage of nations: with a newintroduction. New York: Free press.

Rodríguez, C., Langley, A., Béland, F., \& Denis, J.-L. (2007). Governance, Power, and Mandated Collaboration in an Interorganizational Network. Administration \& Society, 39(2), 150-193. doi:10.1177/0095399706297212

Rogers, E. M. (2003). The Diffusion of innovations (5th ed.). London: Free press. Schumpeter, J. A. (1934). The Theory of Economic Development. Cambridge, MA: Harvard University Press.

Schumpeter, J. A. (1942). Capitalism, socialism, and democracy. Harper: NewYork.

Scott, W. R. (2008). Institutions and Organizations: Ideas and Interest. ThousandOaks, CA: SAGE.

Subagio, U. (2005). Local Government Innovations in Indonesia: Experiences afterthe Decentralization Big Bang in 2001. Paper presented at the Network of Asia-Pacific Schools and Institutes of Public Administration and Governance (NAPSIPAG) Annual Conference 2005, Beijing, PRC,. http://www.napsipag.org/pdf/Decentralization.pdf

TheAsiaFoundation. (2002). Indonesia Rapid Decentralization Appraisal (IRDA):Second Report. Jakarta, Indonesia: The Asia Foundation Retrieved from http://asiafoundation.org/resources/pdfs/1IRDA5english.pdf.

TheAsiaFoundation. (2004). Indonesia Rapid Decentralization Appraisal (IRDA): Fifth Report. Jakarta, Indonesia: The Asia Foundation Retrieved from http://asiafoundation.org/publications/pdf/397.

Thompson, F. J., \& Riccucci, N. M. (1998). Reinventing government. AnnualReview of Political Science, 1(1), 231-257.

Thompson, J. R., \& Ingraham, P. W. (1996). The reinvention game. PublicAdministration Review, 56(3), 291-298.

Thornton, P. H. (2004). Markets from Culture: Institutional Logics and Organizational Decisions in Higher Education Publishing. CA: StanfordUniversity Press.

Thornton, P. H., Jones, C., \& Kury, K. (2005). Institutional Logics and Institutional Change in Organizations: Transformation in Accounting, Architecture, andPublishing. Research in the Sociology of Organizations, 23, 125-170.

Thornton, P. H., \& Ocasio, W. (1999). Institutional logics and the historical contingency of power in organizations: Executive succession in the highereducation publishing industry, 1958-1990 1. American Journal of Sociology, 105(3), 801-843.

Thornton, P. H., \& Ocasio, W. (2008). Institutional Logics. In R. Greenwood, C. Oliver, R. Suddaby, \& K. Sahlin-Andersson (Eds.), The Sage handbook oforganizational institutionalism (pp. 99-129). London: SAGE.

Thornton, P. H., Ocasio, W., \& Lounsbury, M. (2012). The institutional logics perspective: A new approach to culture, structure, and process. Oxford University Press on Demand. Oxford: Oxford University Press on Demand.

Tilcsik, A. (2010). From Ritual to Reality: Demography, Ideologi, and Decoupling in a Post-Communist Government Agency. Academy of Management Journal, 53(6), 1474-1496.

Tracy, S. J. (2013). Qualitative Research Methods: Collecting Evidence, CraftingAnalysis, Communicating Impact. Oxford, UK: Wiley-Blackwell.

Usman, S. (2002). Regional Autonomy in Indonesia: Field Experiences and Emerging Challenges. Paper presented at the The 7th PRSCO Summer Institute / The 4th IRSA International Conference: «Decentralization, Natural Resources, and Regional Development in the Pacific Rim», Bali,June 20 - 21, 2002. http://www.unpan1.un.org/intradoc/groups/public/ documents/.../unpan018238.pdf 
Vigoda-Gadot, E., Shoham, A., Schwabsky, N., \& Ruvio, A. (2005). Public Sector Innovation for the Managerial and the PostManagerial Era: Promises andRealities in a Globalizing Public Administration. International public management journal, $8(1), 57-81$.

Walker, R. M. (2006). Innovation Type and Diffusion: An Empirical Analysis ofLocal Government. Public Administration, 84(2), 311-335.

Walker, R. M., Jeanes, E., \& Rowlands, R. (2002). Measuring Innovation-Applying the Literature Based Innovation Output Indicator to Public Services. Public Administration, 80(1), 201-214.

Worrall, L., Cooper, C. L., \& Campbell-Jamison, F. (2000). The impact of organizational change on the work experiences and perceptions of publicsector managers. Personnel Review, 29(5), 613-636. 